\title{
Exposure to polycyclic aromatic hydrocarbons derived from vehicle exhaust gas induces premature senescence in mouse lung fibroblast cells
}

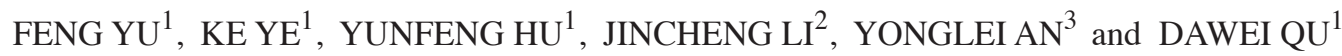 \\ ${ }^{1}$ State Key Laboratory of Automotive Simulation and Control, Jilin University, Changchun, Jilin 130011; \\ ${ }^{2}$ Department of Gastrointestinal Colorectal Surgery, China-Japan Union Hospital, Jilin University, Changchun, Jilin 130033; \\ ${ }^{3}$ Key Laboratory of Groundwater Resources and Environment, Ministry of Education, \\ Jilin University, Changchun, Jilin 130021, P.R. China
}

Received June 14, 2018; Accepted February 19, 2019

DOI: $10.3892 / \mathrm{mmr} .2019 .10086$

\begin{abstract}
Long-term exposure to vehicle exhaust gas may lead to various age-associated disorders, including cardiovascular disease and cancer. Polycyclic aromatic hydrocarbons (PAHs) belong to an important class of carcinogens, which are released into the environment by vehicles and are detectable at high levels in Chinese urban areas. However, whether vehicle exhaust gas (EG), and in particular the PAHs derived from $\mathrm{EG}$, are able to induce cell senescence remains unclear. In the present study, vehicle EG and pure PAHs were used as pollution sources to investigate the effects of long-term exposure to PAH on the cellular processes occurring in mouse lung fibroblast cells (mLFCs). Using cell proliferation and apoptosis assays, it was demonstrated that benzopyrene (BaP) suppressed the proliferation of mLFCs, and benzanthracene (BaA) and $\mathrm{BaP}$ induced cell apoptosis. Molecular analysis suggested that long-term exposure to $\mathrm{BaA}$ and $\mathrm{BaP}$ was able to increase the protein expression levels of p53, p21 and the apoptotic factors involved in the caspase cascade, including caspase-3 and -9. Notably, the present study suggested that PAH exposure was able to promote cell senescence in mLFCs by activating the ATM serine/threonine kinase/H2A histone family member $\mathrm{X}$ pathway. The present study may provide novel insights into the underlying mechanism of vehicle EG and PAHs in promoting the development of age-associated diseases.
\end{abstract}

\section{Introduction}

In recent years, due to the development of the Chinese economy, the severity of problems associated with air pollution has

Correspondence to: Professor Dawei Qu, State Key Laboratory of Automotive Simulation and Control, Jilin University, 2699 Qianjin Road, Changchun, Jilin 130011, P.R. China

E-mail: eewang404@163.com

Key words: vehicle exhaust gas, polycyclic aromatic hydrocarbons, cell senescence, DNA methylation, ATM serine/threonine kinase increased. Vehicle exhaust gas (EG) serves a principal role in air pollution and may induce various age-associated disorders, including cognitive dysfunction $(1,2)$, metabolic dysregulation $(3,4)$, cardiovascular disease $(5,6)$ and cancer $(7,8)$. Numerous studies have investigated the mechanisms underlying EG-associated disorders; DNA damage, epigenetic alterations, inflammation and oxidative stress have been identified to serve a role in these disorders (9-11).

Among the various chemical compounds identified in vehicle EG, polycyclic aromatic hydrocarbons (PAHs) are a group of chemicals containing at least two fused benzene rings without heteroatoms (12). PAHs may be released as a result of an incomplete combustion of derivatives of coal, petroleum or organic polymers. However, in urban zones, PAHs are primarily released from the engines of vehicles, suggesting that vehicle EG is the major source of PAHs in air pollution (13). The estimated concentration of PAHs in EG ranges between 200 and 500 parts per million, according to our previous study (data not published). Inhalation of PAH-containing air may increase the risk of lung cancer in humans; Osgood et al (14) demonstrated that PAHs may induce inflammation and tumorigenesis in mouse lung cells by activating extracellular signal-regulated kinase $1 / 2$, p38 mitogen-activated protein kinase (MAPK) and inflammatory-associated genes, including cyclooxygenase 2 and chemokine ligand 2. Eom et al (15) conducted a pilot nested case-control study to examine the effects of exposure to PAH on lung carcinogenesis and identified that oxidative stress induced by exposure to $\mathrm{PAH}$ may be an important risk factor for lung cancer development. Furthermore, Zhao et al (16) demonstrated that benzopyrene (BaP) may promote lung cancer cell metastasis by activating the tumor necrosis factor- $\alpha$ signaling pathway. Additionally, accumulating evidence demonstrated that PAH may induce the methylation of genes involved in the development of cancer; White et al (17) demonstrated that PAH exposure is associated with hypomethylation and hypermethylation of various promoter regions in breast cancer. Additionally, Kim et al (18) identified that lipophilic PAHs contribute to the pathogenesis of insulin resistance through methylation-mediated suppression of the insulin receptor substrate 2 gene. 
Zhu et al (19) and our previous studies (data not published) identified three principal types of $\mathrm{PAH}$ in vehicle EG derived from a gasoline internal combustion engine: Benzanthracene (BaA), BaP and benzoperylene (BEP). Additionally, our previous studies identified that exposure to vehicle EG may immunocompromise BALB/C mice (data not published). However, whether exposure to vehicle EG, particularly PAHs, is able to induce cell senescence remains unknown.

In the present study, vehicle EG and pure PAHs were used to simulate polluted air, and the cellular events following long-term PAH exposure were investigated by analyzing mouse lung fibroblast cells (mLFCs). PAHs were revealed to induce apoptosis of mLFCs, promoting various apoptosis-associated factors. Notably, PAHs induced cell senescence in mLFCs by activating the ATM serine/threonine kinase (ATM)/H2A histone family member $\mathrm{X}(\mathrm{H} 2 \mathrm{AX})$ pathway. However, the epigenetic status of the promoter of senescence-associated genes, including p16, was not affected by exposure to PAHs. The present study may provide novel insights into the underlying mechanism of vehicle EG and PAHs in promoting the development of age-associated diseases.

\section{Materials and methods}

Animals and exposure model. A total of $24 \mathrm{BALB} / \mathrm{C}$ mice (12 male and 12 female, 6-8 weeks old, 16-18 g; Beijing Vital River Laboratory Animal Technology Co., Ltd., Beijing, China) were exposed to EG (6 males and 6 females) or clean air (6 males and 6 females). Mice were housed at $25^{\circ} \mathrm{C}$ with $50-80 \%$ relative humidity under a 12:12-h light/dark cycle, with access to food and water ad libitum. The mice were placed in a cage in a sealed chamber (Fig. 1). Gas exposure (GE) was performed for $5 \mathrm{~h}$ /day (between 9.00 a.m. and 2.00 p.m.), 5 consecutive days per week, for 6 weeks in an exposure chamber (Fig. 1A). Following 30 days of treatment, mice were sacrificed, and the lung tissues were collected for further molecular experiments (Fig. 1B and C). EG was collected from a gasoline internal combustion engine and mixed with fresh air in a ratio of 1:10 using the electromechanical injection system. Subsequently, the mixed gas was injected into the chamber at a flow rate of $3 \mathrm{l} / \mathrm{min}$. All animal experiments were approved by The Animal Care and Use and Ethics Committee of Jilin University (Changchun, China).

Cell culture. A male BALB/C mouse, housed under clean air conditions (no GE), was sacrificed, and the fresh lung tissues were cut into $\sim 1 \mathrm{~mm}^{3}$ pieces (Fig. $1 \mathrm{E}$ and F). Subsequently, the lung tissues were seeded in a 6 -well plate and dried in a flow tissue culture hood for 15 min until the tissues attached to the plate surface. A total of $500 \mu \mathrm{l}$ Dulbecco's modified Eagle's medium (HyClone; GE Healthcare Life Sciences, Logan, MT, USA) supplemented with $10 \%$ fetal bovine serum (HyClone; GE Healthcare Life Sciences) and antibiotics $(100 \mathrm{mg} / \mathrm{ml}$ streptomycin and $100 \mathrm{U} / \mathrm{ml}$ penicillin; HyClone; GE Healthcare Life Sciences) was added to the culture plates and the plates were incubated at $37^{\circ} \mathrm{C}$ in a humidified incubator with $5 \% \mathrm{CO}_{2}$ (Thermo Fisher Scientific, Inc., Waltham, MA, USA). The medium was replaced every other day until mLFC proliferation was observed under a light microscope (ECLIPSE Ts2; Nikon Corporation, Tokyo, Japan).

Cell proliferation assay. $\mathrm{mLFCs}\left(5 \times 10^{3}\right)$ were treated with $3 \mu \mathrm{M}$ BaA, BaP or BEP (Sigma-Aldrich; Merck KGaA, Darmstadt, Germany) for $72 \mathrm{~h}$, as previously described (20). Subsequently, cell proliferation was determined using the water-soluble tetrazolium salt (WST-1) cell proliferation reagent (Beyotime Institute of Biotechnology, Haimen, China). Briefly, $20 \mu \mathrm{l}$ WST-1 reagent was added to $200 \mu \mathrm{l}$ cell culture medium and incubated at $37^{\circ} \mathrm{C}$ in the dark for $2.5 \mathrm{~h}$. The optical density (OD) at 450 and $630 \mathrm{~nm}$ was measured using a microplate reader (Synergy H1; BioTek Instruments, Inc., Winooski, VT, USA). Final OD values were calculated using the following formula: $\mathrm{OD}_{\text {final }}=\mathrm{OD}_{450}-\mathrm{OD}_{630}-\mathrm{OD}_{\text {blank }}$.

Cell apoptosis. Following treatment with $3 \mu \mathrm{M}$ BaA, BaP or BEP for $72 \mathrm{~h}$, cell apoptosis was determined by staining mLFCs with propidium iodide (PI) and Annexin V-fluorescein isothiocyanate (FITC). Cells $\left(1 \times 10^{6}\right)$ were washed with PBS and centrifuged at $200 \mathrm{x}$ g for $5 \mathrm{~min}$ at room temperature. The cellular pellet was suspended in $50 \mu \mathrm{l}$ Annexin V solution containing $5 \mu \mathrm{l}$ Annexin V-FITC and $5 \mu \mathrm{l}$ PI for $15 \mathrm{~min}$ at room temperature, provided in the Annexin V-FITC Apoptosis Detection kit (BD Biosciences, Franklin Lakes, NJ, USA). Data acquisition and data analysis were performed using a flow cytometer (FACScan; Becton-Dickinson and Company, Franklin Lakes, NJ, USA) with the FlowJo FACS analysis software (version 10.0; FlowJo LLC, Ashland, OR, USA).

Protein extraction and western blotting. Total protein was extracted from mLFCs treated with $\mathrm{BaA}$ and $\mathrm{BaP}$ using a lysis buffer containing $50 \mathrm{mM}$ Tris/acetate ( $\mathrm{pH}$ 7.4), 1 mM EDTA, $0.5 \%$ Triton $\mathrm{X}-100,150 \mathrm{mM}$ sodium chloride and $0.1 \mathrm{mM}$ phenylmethane sulfonyl fluoride. Total protein was quantified using a Bradford protein assay kit (Beyotime Institute of Biotechnology). Proteins (20 $\mu \mathrm{g} / \mathrm{lane})$ were separated by 8-10\% SDS-PAGE and subsequently transferred to polyvinylidene difluoride (PVDF) membranes (EMD Millipore, Billerica, MA, USA). The PVDF membranes were incubated in Tris-buffered saline buffer containing $0.5 \%$ Tween-20 (Sigma-Aldrich; Merck KGaA) and 5\% skim milk at room temperature for $1 \mathrm{~h}$ and subsequently incubated at $4^{\circ} \mathrm{C}$ overnight with the following primary antibodies (all 1:1,000 dilution): Anti-p53 (cat. no. ab26; Abcam, Cambridge, UK), anti-p21 (cat. no. ab109199; Abcam), anti-cleaved caspase-3 (cat. no. 9661; Cell Signaling Technology, Inc., Danvers, MA, USA), anti-cleaved caspase-9 (cat. no. 9509; Cell Signaling Technology, Inc.), anti-p16 (cat. no. ab189034; Abcam), anti-p27 ${ }^{\mathrm{KIP} 1}$ (cat. no. ab193379; Abcam), anti-ATM, (cat. no. ab78; Abcam), anti-H2AX (cat. no. 7631; Cell Signaling Technology, Inc.) anti- phosphorylated-H2AX ( $\gamma \mathrm{H} 2 \mathrm{AX}$; cat. no. 07-164, EMD Millipore) and anti- $\beta$-actin (cat. no. sc-47778; Santa Cruz Biotechnology, Inc., Dallas, TX, USA). Following incubation with the primary antibodies, membranes were incubated with horseradish peroxidase-conjugated goat anti-rabbit (cat. no. sc-2004; Santa Cruz Biotechnology, Inc.) or goat anti-mouse (cat. no. sc-2005; Santa Cruz Biotechnology, Inc.) immunoglobulin $\mathrm{G}$ secondary antibodies at room temperature for $1 \mathrm{~h}$ (1:3,000 dilution). The immunoreactivity 
was detected using an enhanced chemiluminescence detection kit (EMD Millipore). The densitometric analysis was performed using Quantity One software (version 4.6; Bio-Rad Laboratories, Inc., Hercules, CA, USA).

Senescence-associated $\beta$-galactosidase (SA- $\beta$-Gal) staining. mLFCs were treated with $3 \mu \mathrm{M} \mathrm{BaA}$ or BaP for $72 \mathrm{~h}$. Cellular senescence was analyzed by measuring the activity of SA- $\beta$-Gal. mLFCs were collected and fixed with $3 \%$ formaldehyde (Beijing Chemical Works, Beijing, China) for 3 min at room temperature. After washing with PBS, cell senescence was determined with the Senescence $\beta$-Galactosidase Staining kit according to the manufacturer's protocol (Beyotime Institute of Biotechnology). Images of the cells were captured using a light microscope and cells positive for $\beta$-Gal staining were subsequently counted.

Detection of telomere length in $m L F C$. The relative average telomere length of mLFCs was measured using total genomic mouse DNA as template, using quantitative polymerase chain reaction (qPCR), as previously described by Callicott and Womack (21), with certain modifications. Total genomic DNA was extracted from control, and $\mathrm{BaA}$ - and $\mathrm{BaP}-$ treated mLFCs using the Qiagen DNeasy Blood \& Tissue kit (Qiagen China Co., Ltd., Shanghai, China). The primers used for the analysis were: Forward, 5'-CGGTTTGTTTGGGTTTGG GTTTGGGTTTGGGTTTGGGTT-3' and reverse, 5'-GGC TTGCCTTACCCTTACCCTTACCCTTACCCTTACCCT-3'.

Ribosomal protein lateral stalk subunit P0 (RPLP0) gene was used as the reference gene. The following primers were used to amplify RPLP0: Forward, 5'-ACTGGTCTAGGACCCGAG AAG-3' and reverse, 5'-TCAATGGTGCCTCTGGAGATT-3'. The qPCR reaction mixture to investigate telomere length and RPLP0 comprised $12.5 \mu 1$ 2x SYBR-Green master mix (Roche Applied Science, Penzberg, Germany), $2.5 \mu$ l of each primer at a concentration of $300 \mathrm{nM}$ and $20 \mathrm{ng}$ genomic DNA; double-distilled water was added to a total volume of $25 \mu$. The PCR thermocycling conditions conducted to determine telomere length were as follows: Initial denaturation at $95^{\circ} \mathrm{C}$ for $10 \mathrm{~min}$, followed by 30 cycles of $95^{\circ} \mathrm{C}$ for $15 \mathrm{sec}$ and $56^{\circ} \mathrm{C}$ for $1 \mathrm{~min}$, and final extension at $72^{\circ} \mathrm{C}$ for $5 \min (\mathrm{ABI} 7500$; Applied Biosystems; Thermo Fisher Scientific, Inc.). The PCR thermocycling conditions for RPLP0 detection were as follows: Initial denaturation at $95^{\circ} \mathrm{C}$ for $10 \mathrm{~min}$, followed by 35 cycles of $95^{\circ} \mathrm{C}$ for $15 \mathrm{sec}, 52^{\circ} \mathrm{C}$ for $20 \mathrm{sec}$ and $72^{\circ} \mathrm{C}$ for $30 \mathrm{sec}$, and final extension at $72^{\circ} \mathrm{C}$ for $5 \mathrm{~min}$. Telomere length was assessed by calculating the relative ratio between telomeres and RPLP0. The $2^{-\Delta \Delta C q}$ quantification method (22) was used to quantify the qPCR results.

Detection of gene expression levels by reverse transcription-qPCR (RT-qPCR) and semi-quantitative PCR. Total RNA was extracted from mLFCs using the Qiagen RNeasy Mini kit (Qiagen China Co., Ltd.). Total RNA (800 ng) was reverse transcribed to cDNA using Moloney murine leukemia virus reverse transcriptase (Invitrogen; Thermo Fisher Scientific, Inc.) according to the manufacturer's protocol. The qPCR reaction mixture contained: $2 \mu \mathrm{l}$ cDNA, $4 \mu \mathrm{l} 2 \mathrm{X}$ Taq PCR StarMix buffer (GenStar, Beijing, China) and $2 \mu \mathrm{l}$ of each primer. The semi-quantitative PCR amplification was performed using the GeneQ cycler (Hangzhou Bori Technology Co., Ltd., Hangzhou, China) and the thermocycling conditions were as follows: Initial denaturation at $98^{\circ} \mathrm{C}$ for $3 \mathrm{~min}$, followed by $26-32$ cycles of $95^{\circ} \mathrm{C}$ for $15 \mathrm{sec}, 62^{\circ} \mathrm{C}$ for $15 \mathrm{sec}$ and $72^{\circ} \mathrm{C}$ for $15 \mathrm{sec}$, and a final extension step at $72^{\circ} \mathrm{C}$ for $5 \mathrm{~min}$. The qPCR reaction was performed as follows: Initial denaturation at $95^{\circ} \mathrm{C} 10 \mathrm{~min}$, followed by 40 cycles of $95^{\circ} \mathrm{C}$ for $10 \mathrm{sec}$ and $60^{\circ} \mathrm{C}$ for $30 \mathrm{sec}$. The primer sequences used were as follows: p16, forward, 5'-GAGCCATCTGGAGCAGCA TGGAG-3' and reverse, 5'-GCCCATCATCATCACCTGAAT C-3'; p27 $7^{\mathrm{KIP} 1}$, forward, 5'-TGGGTTAGCGGAGCAGTGTC-3' and reverse, 5'-CTCCACAGTGCCAGCGTTC-3'; and $\beta$-actin, forward, 5'-CAGGTCATCACTATTGGCAACGAGC-3' and reverse, 5'-CGGATGTCAACGTCACACTTCATGA-3'. For semi-quantitative PCR, the reaction products were separated on a 3\% agarose gel and visualized by ethidium bromide. The densitometric analysis was performed using Quantity One software (version 4.6; Bio-Rad Laboratories, Inc.).

DNA methylation analysis. Mice were exposed to exhaust gas for 30 days, and the $\mathrm{CpG}$ methylation state of the promoter of p16 was analyzed. Genomic DNA was extracted from mouse lung tissues, and control and $3 \mu \mathrm{M}$ BaP-treated mLFCs. In total, 1,000 ng was used for bisulfite conversion with the QIAamp DNA Mini kit (Qiagen China Co., Ltd.) according to the manufacturer's protocol. PCR was performed using PrimeSTAR ${ }^{\circledR}$ HS DNA Polymerase mix (cat. no. R044A; Takara Bio, Inc., Otsu, Japan). PCR thermocycling conditions were as follows: Initial denaturation at $97^{\circ} \mathrm{C}$ for $10 \mathrm{~min}$, followed by 35 cycles of $96^{\circ} \mathrm{C}$ for $30 \mathrm{sec}, 60^{\circ} \mathrm{C}$ for $30 \mathrm{sec}, 72^{\circ} \mathrm{C}$ for $30 \mathrm{sec}$, and a final extension at $72^{\circ} \mathrm{C}$ for $5 \mathrm{~min}$. The primers used for assessing DNA methylation were as follows: Forward, 5'-GAGTTATTT GGAGTAGTATGGAG-3' and reverse, 5'-ACCCATCATCAT CACCTAAATC-3'. The PCR products were separated on $2 \%$ agarose gel and purified with a DNA gel extraction kit (Tiangen Biotech Co., Ltd., Beijing, China). Subsequently, the PCR products were cloned into a CloneJET vector using a PCR Cloning kit (Thermo Fisher Scientific, Inc.) and subjected to Sanger sequencing (Sangon Biotech Co., Ltd., Shanghai, China) for analysis of the methylation state of the p16 promoter.

Statistical analysis. SPSS 17.0 software (SPSS, Inc., Chicago, IL, USA) was used for statistical analysis. All experiments were repeated at least three times, and data are presented as the means \pm standard deviation. Statistical significance was determined using Student's t-test or one-way analysis of variance followed by Fisher's least significant difference post hoc test. $\mathrm{P}<0.05$ was considered to indicate a statistically significant difference.

\section{Results}

$m L F C$ harvesting. Extracted tissues were cut and cultured for 10 days, after which, mLFCs began to proliferate (Fig. 1G). After 7 additional days, mLFCs were trypsinized and transferred to a tissue culture plate for subsequent experiments (Fig. 1H).

PAH induces $m L F C$ apoptosis. mLFCs were treated with $3 \mu \mathrm{M}$ $\mathrm{BaA}, \mathrm{BaP}$ or BEP for $72 \mathrm{~h}$, and cell proliferation was assessed 
A
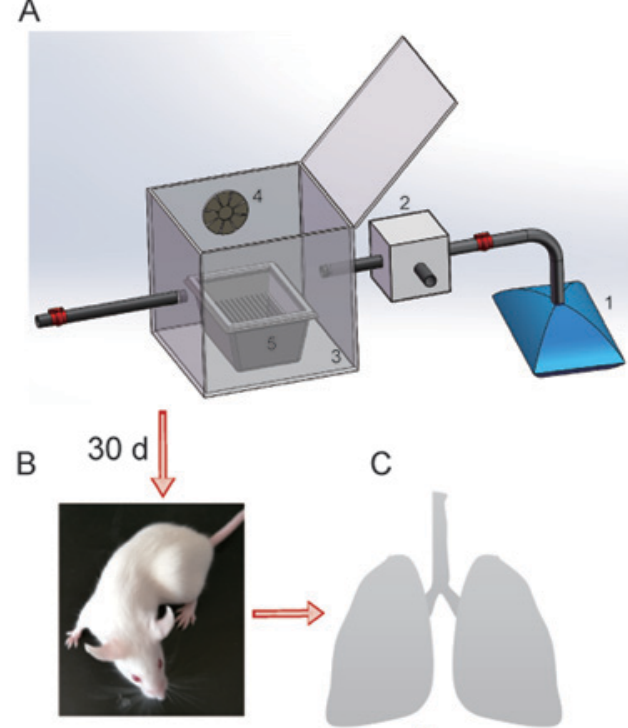
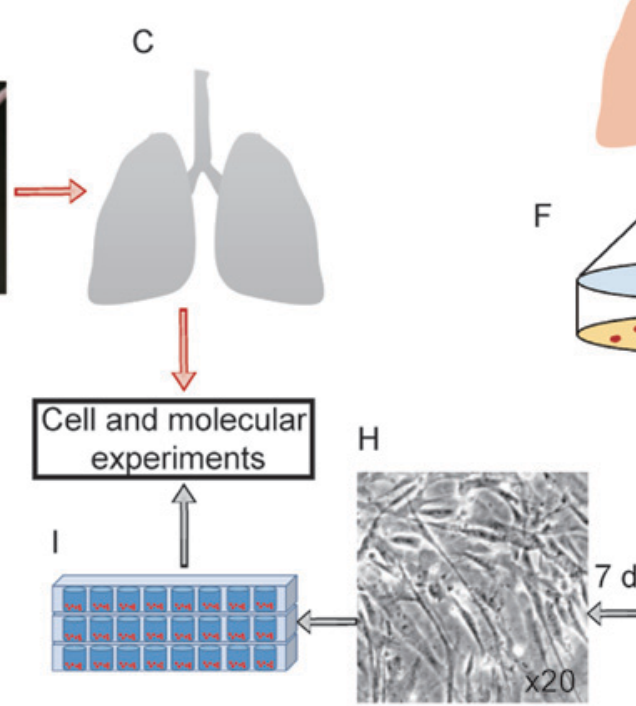

D

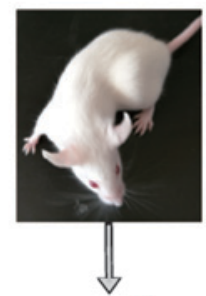

$\mathrm{E}$

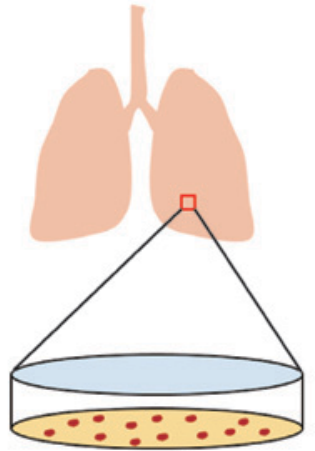

$10 \mathrm{~d}$

G

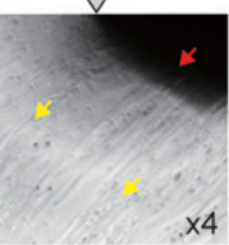

Figure 1. Isolation of mLFCs and establishment of EG and polycyclic aromatic hydrocarbons exposure model. (A) Diagram of the exposure chamber, consisting of five principal components: 1, Gas collecting bag; 2 , controlled electromechanical injection system; 3 , inhalation chamber; 4 , air-mixing fan; 5 , mouse cage. (B and C) BALB/C mice were exposed to EG for 30 days and sacrificed. Lung tissues were collected for molecular experiments. (D-F) Mice were sacrificed, lung tissues were collected and mLFCs were isolated. (G-I) mLFCs were culture-expanded and used for subsequent experiments. (G) Magnification, $\mathrm{x} 4$; (H) magnification, x20. Red arrow, mouse lung tissue; orange arrows, mLFCs. EG, exhaust gas; d, days; mLFC, mouse lung fibroblast cell.

using the WST-1 assay. mLFC proliferation was significantly suppressed following treatment with BaP, and proliferation was decreased by $\sim 18 \%$ (P<0.01; Fig. 2A). Treatment with BaA decreased proliferation by $11 \%$; however, the difference was not significant $(\mathrm{P}=0.13)$. Treatment with BEP did not alter cell proliferation. Cell apoptosis was subsequently determined by flow cytometry. Compared with the control group, cell apoptosis was increased by $7.8,19.8$ and $3.5 \%$ in the $\mathrm{BaA}, \mathrm{BaP}$ and BEP groups, respectively (Fig. 2B). Treatment with BaP led to the highest apoptosis rate.

The protein expression levels of factors associated with cell growth and apoptosis were analyzed by western blotting (Fig. 3A). The results revealed that following treatment with $3 \mu \mathrm{M} \mathrm{BaA}$ or $\mathrm{BaP}$, the protein expression levels of $\mathrm{p} 53$ and p21 were significantly increased. The protein expression levels of p53 and p21 were increased 1.7- and 2.7-fold in the BaA group, respectively (Fig. 3B). Furthermore, following treatment with $\mathrm{BaP}$, the protein expression levels of p53 and p21 increased 1.9- and 3.9-fold, respectively (Fig. 3B). Additionally, the caspase-dependent cell apoptosis pathway was activated. The protein expression levels of cleaved caspase-3 and cleaved caspase-9 were increased 4.2- and 5.4-fold in the BaA group, and 4.0- and 7.5-fold in the BaP group, respectively $(\mathrm{P}<0.01)$.

PAH induces premature senescence in $m L F C$ s. A previous study demonstrated that long-term exposure to polluted air may cause biological aging and age-associated diseases (9). In the present study, PAH was hypothesized to induce premature senescence. Therefore, mLFCs were exposed to PAH for $72 \mathrm{~h}$ and senescence was examined. mLFCs treated with PAH were positive for SA- $\beta$-Gal activity (Fig. 4A). Compared with the control group, the number of cells positive for SA- $\beta-\mathrm{Gal}$ in the $\mathrm{BaA}$ and $\mathrm{BaP}$ groups was increased 2.1- and 4.6-fold, respectively $(\mathrm{P}<0.01$; Fig. 4A). To further investigate whether cell senescence was associated with a decrease in telomere lengths, the telomeric regions were investigated using qPCR. No significant differences in telomere lengths between the control group and the samples exposed to PAH were identified ( $\mathrm{P}>0.05$; Fig. $4 \mathrm{~B}$ ), suggesting that PAH may promote cell senescence via the environment stress-induced premature senescence (SIPS) pathway and not via the replicative senescence (RS) pathway $(23,24)$.

The expression levels of two senescence-associated factors, p16 and p27, were subsequently quantified (25-27). BaP exhibted the most notable effect on the induction of premature senescence (Fig. 4A); therefore, it was selected as the pollutant for subsequent experiments. Using semi-quantitative PCR, RT-qPCR and western blotting, the mRNA and protein expression levels of p16 and p27 were revealed to be significantly increased following treatment with $\mathrm{BaP}$ ( $\mathrm{P}>0.01$, Fig. 4C-E).

PAH does not influence the DNA methylation state of the p16 promoter. Cellular senescence is associated with the expression 


\section{A}

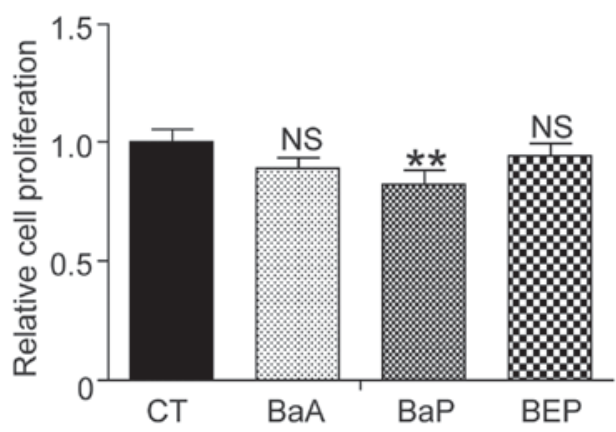

B
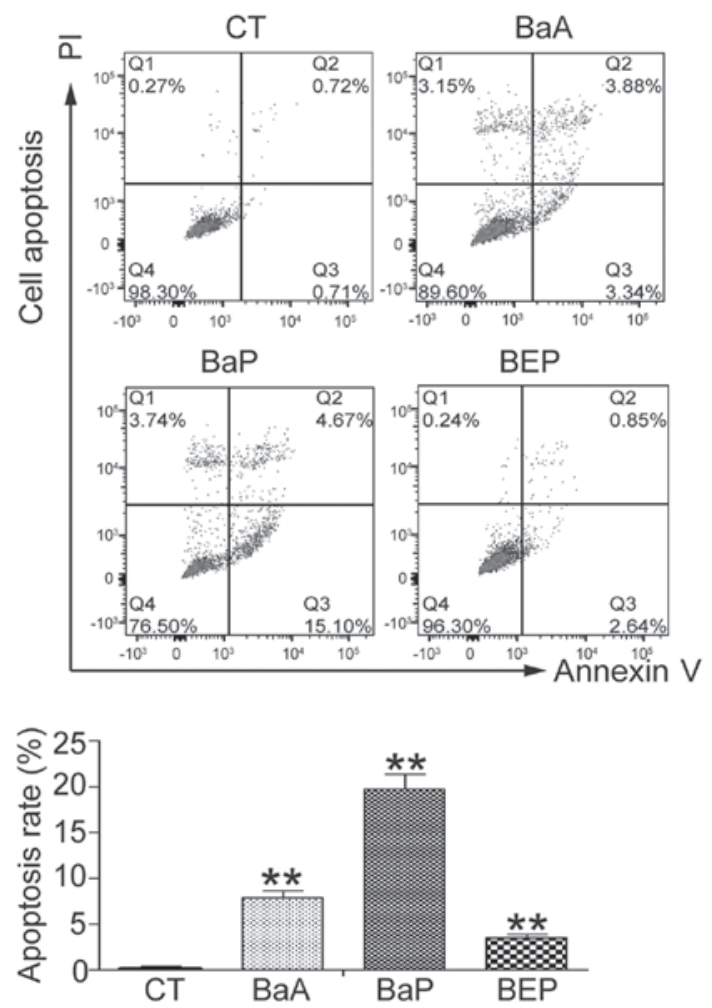

Figure 2. PAHs suppress proliferation and induce apoptosis of mLFCs. (A) $\mathrm{mLFC}$ proliferation was significantly decreased following exposure to BaP. (B) Flow cytometry and quantification of apoptosis rate suggested that PAHs may induce cell apoptosis. ${ }^{* *} \mathrm{P}<0.01$ vs. the $\mathrm{CT}$ group. BaA, benzanthracene; BaP, benzopyrene; BEP, benzoperylene; CT, control; mLFC, mouse lung fibroblast cell; NS, not significant; PAHs, polycyclic aromatic hydrocarbons; PI, propidium iodide.

levels of p16, which is regulated by the methylation state of its promoter region (28). Since the present results suggested that PAHs may promote premature senescence and activate p16 in mLFCs, the DNA methylation state of the promoter of p16 was investigated following long-term exposure to EG or treatment with BaP. However, DNA sequencing results suggested that the methylation levels were similar between the control and the experimental groups (Fig. 5). The present results suggested that the premature senescence and the increase in the expression levels of p16 induced by PAHs were not associated with epigenetic alterations.

PAH exposure activates the ATM/H2AX pathway. A previous study reported that ATM is involved in senescence downstream to various stimuli, including hyperproliferation and DNA damage (29). In response to DNA damage, ATM induces H2AX
A

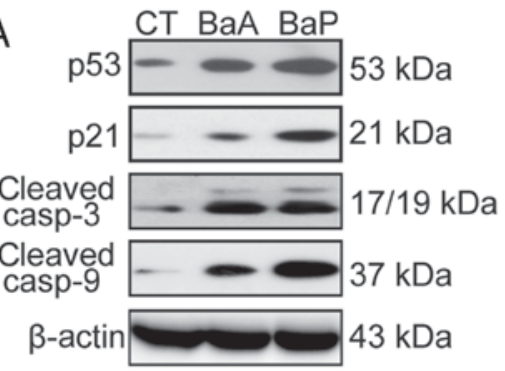

B p53 p21
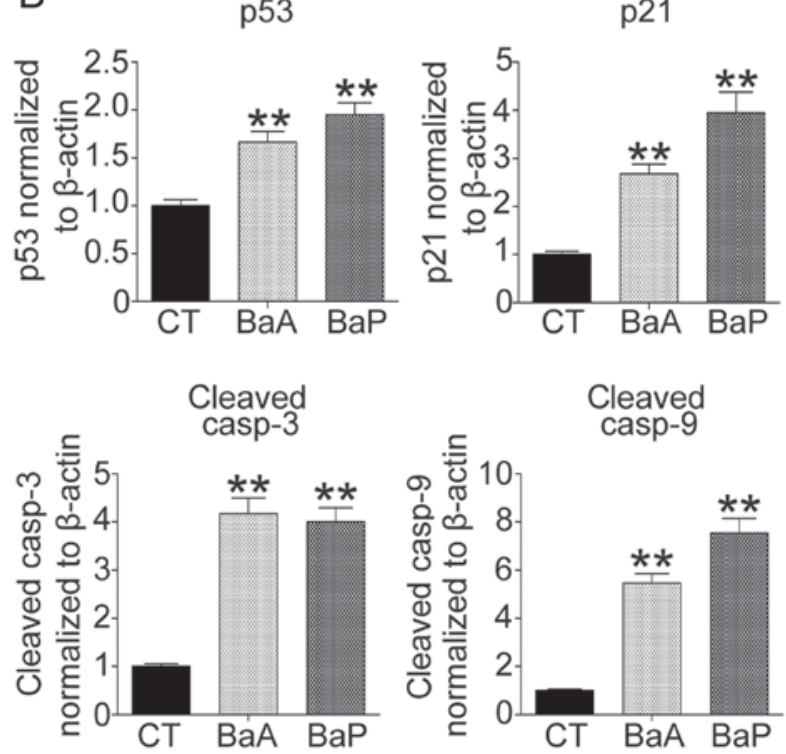

Figure 3. Exposure to $\mathrm{BaA}$ and $\mathrm{BaP}$ promotes the protein expression levels of factors associated with cell proliferation and apoptosis. (A) Protein expression levels of apoptosis-associated factors were detected by western blotting. (B) Densitometric analysis. ${ }^{* *} \mathrm{P}<0.01$ vs. the $\mathrm{CT}$ group. $\mathrm{BaA}$, benzanthracene; $\mathrm{BaP}$, benzopyrene; casp, caspase; CT, control.

phosphorylation at serine 139 , resulting in the phosphorylation of H2AX and an increase of $\gamma \mathrm{H} 2 \mathrm{AX}$ foci at the DNA damage sites $(30,31)$. In the present study, the ATM/H2AX pathway was activated following exposure to PAHs. Western blot analysis results suggested that exposure to $\mathrm{EG}$ and $\mathrm{PAH}$ induced a significant upregulation of ATM and $\gamma \mathrm{H} 2 \mathrm{AX}$ (Fig. 6). The protein expression levels of ATM were increased 2.5- and 3.6-fold in the GE group and PAH group, respectively. Furthermore, the protein expression levels of $\gamma \mathrm{H} 2 \mathrm{AX}$ were increased 1.5- and 2.0-fold in the GE group and PAH group, respectively.

\section{Discussion}

Vehicle EG contains various chemical compounds including carbon dioxide, hydrocarbons and nitrogen oxide, and it is important to investigate the biological effects of these components. PAHs are a group of toxic pollutants present in vehicle EG. Although PAHs are involved in the pathological progression of various tumors (32), the role of PAHs in cell senescence remains unclear. In the present study, under laboratory conditions, the biological effects of PAHs were investigated on mouse lungs and mLFCs. Cell proliferation was examined following exposure to PAHs for $72 \mathrm{~h}$, and BaP, a type of $\mathrm{PAH}$, significantly suppressed proliferation of mLFCs. Additionally, $\mathrm{BaA}$ and $\mathrm{BaP}$ were able to induce apoptosis of mLFCs. The 
A

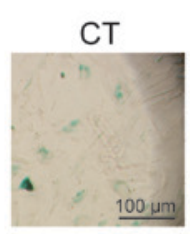

B
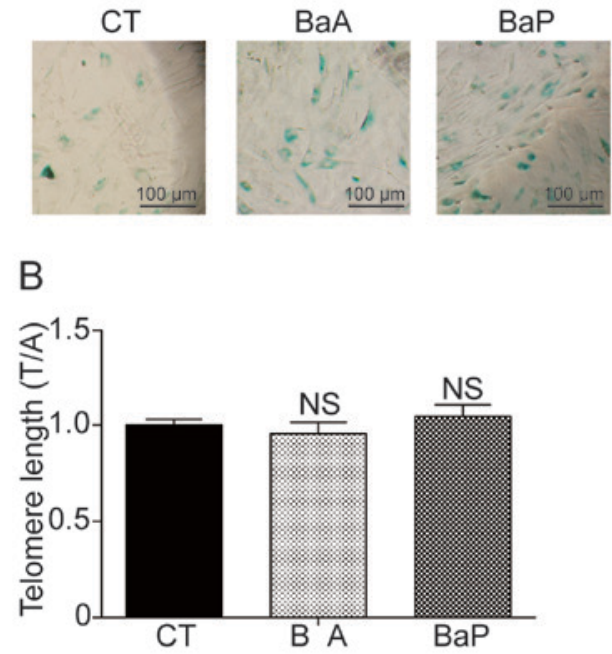

C
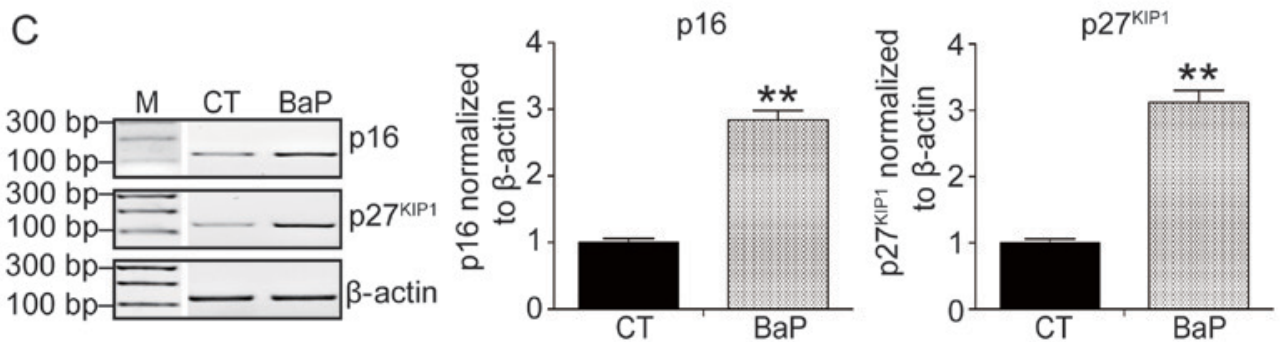

D
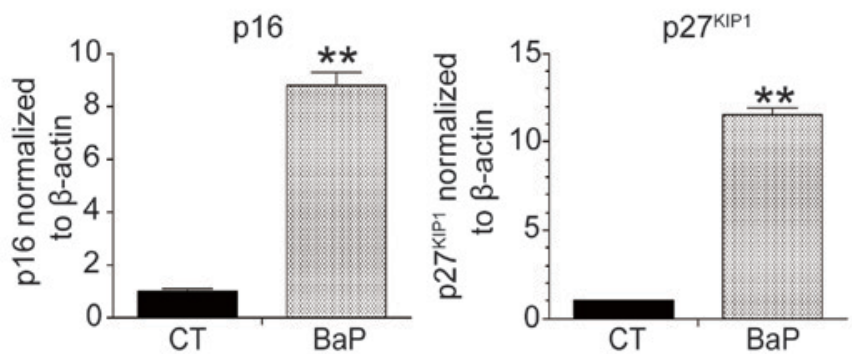

$\mathrm{E}$
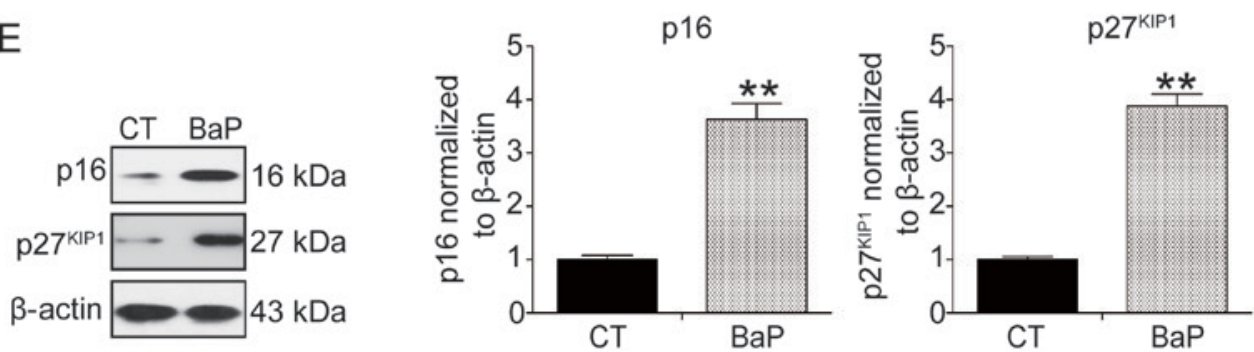

Figure 4. PAH exposure induces premature senescence in mLFCs. (A) Cellular senescence was determined by senescence-associated $\beta$-Gal staining. (B) Relative telomere length of mLFCs was measured by qPCR. (C) mRNA expression levels of p16 and p27 were determined by semi-quantitative PCR (inverted color). (D) mRNA expression levels of p16 and p27 were determined by reverse transcription-qPCR. (E) Protein expression levels of p16 and p27 in mLFCs exposed to PAHs were determined by western blotting. ${ }^{* *} \mathrm{P}<0.01$ vs. the $\mathrm{CT}$ group; ${ }^{*} \mathrm{P}<0.01$ vs. the BaA group. $\beta$-Gal, $\beta$-galactosidase; BaA, benzanthracene; BaP, benzopyrene; CT, control; M, marker; mLFC, mouse lung fibroblast cell; NS, not significant; qPCR, quantitative polymerase chain reaction; $\mathrm{T} / \mathrm{A}$, the ratio between the copies of telomere and the copies of the reference gene.

molecular factors associated with apoptosis, including p53,p21, cleaved caspase-3 and cleaved caspase-9, were significantly upregulated following treatment with BaA and BaP. BEP did not significantly alter cell proliferation compared with the control, and exhibited a markedly reduced effect on apoptosis compared with $\mathrm{BaA}$ and $\mathrm{BaP}$. Therefore, $\mathrm{BaA}$ and $\mathrm{BaP}$ were selected for further molecular experiments. A previous study suggested that the cytotoxic effects of $\mathrm{BaA}, \mathrm{BaP}$ and $\mathrm{BEP}$ are distinct due to their differential potential to activate the aryl hydrocarbon receptor signaling pathway (33).

Two types of pathways may regulate cellular senescence: RS and SIPS. RS is induced by serial passage of normal cells 
A

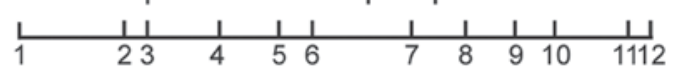

B

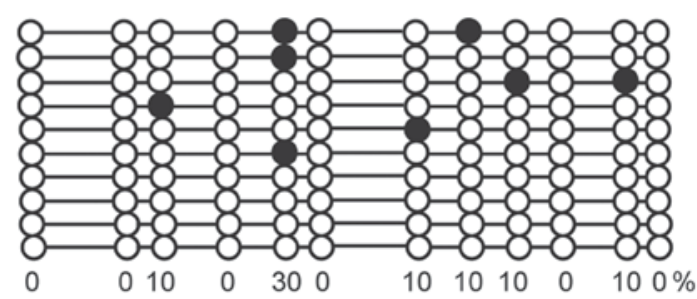

MR

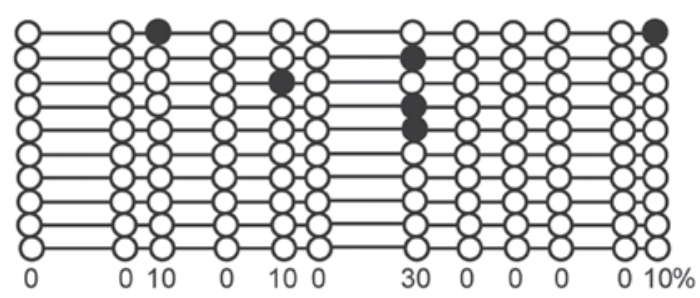

D
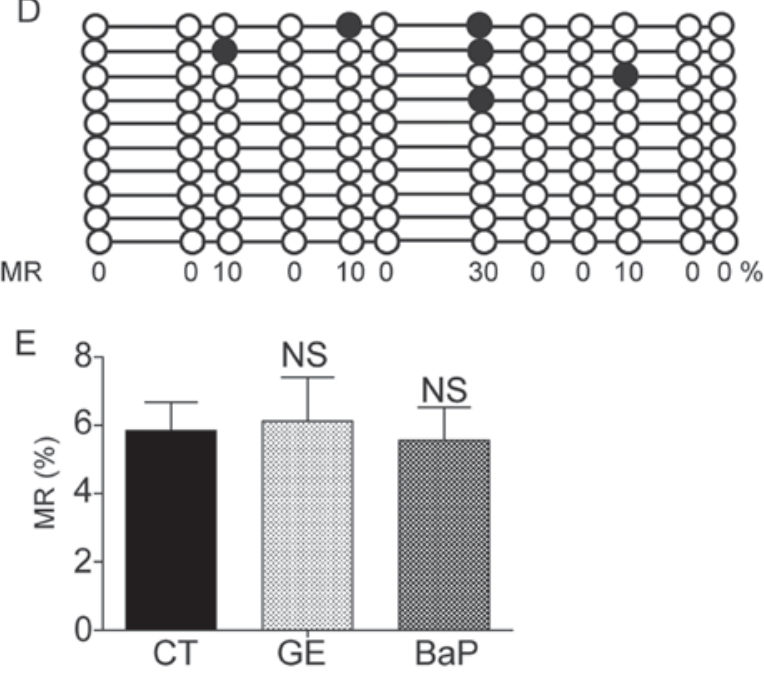

Figure 5. DNA methylation analysis of the p16 promoter. (A) Schematic diagram of the $\mathrm{CpG}$ islands on the p16 promoter. (B) p16 DNA methylation state of normal mLFCs. (C) p16 DNA methylation state of lung tissue following exposure to exhaust gas for 30 days. (D) p16 DNA methylation state of mLFCs following treatment with $3 \mu \mathrm{M}$ BaP for $72 \mathrm{~h}$. (E) Quantification of the total methylation rate in the three groups. White circles represent unmethylated $\mathrm{CpGs}$, black circles represent methylated CpGs. BaP, benzopyrene; CT, control; GE, gas exposure; mLFC, mouse lung fibroblast cell; MR, methylation rate; NS, not significant.

in culture, whereas SIPS is primarily induced by exposure to environmental stimuli, including radiation and chemical toxicants (24). RS is associated with telomere shortening and epigenetic alterations, whereas SIPS is associated with DNA damage and genetic mutations. In the present study, it was demonstrated that $\mathrm{BaA}$ and $\mathrm{BaP}$ may promote cell senescence by increasing the expression levels of the senescence-associated factors p16 and p27 in mLFCs. Since telomere shortening is an important marker of RS (34), the lengths of telomeres were investigated in the PAH exposure group and in the control group. However, no significant difference between the two groups was observed.

PAHs may form reactive epoxides in cells, covalently binding to the DNA. These epoxides may induce epigenetic
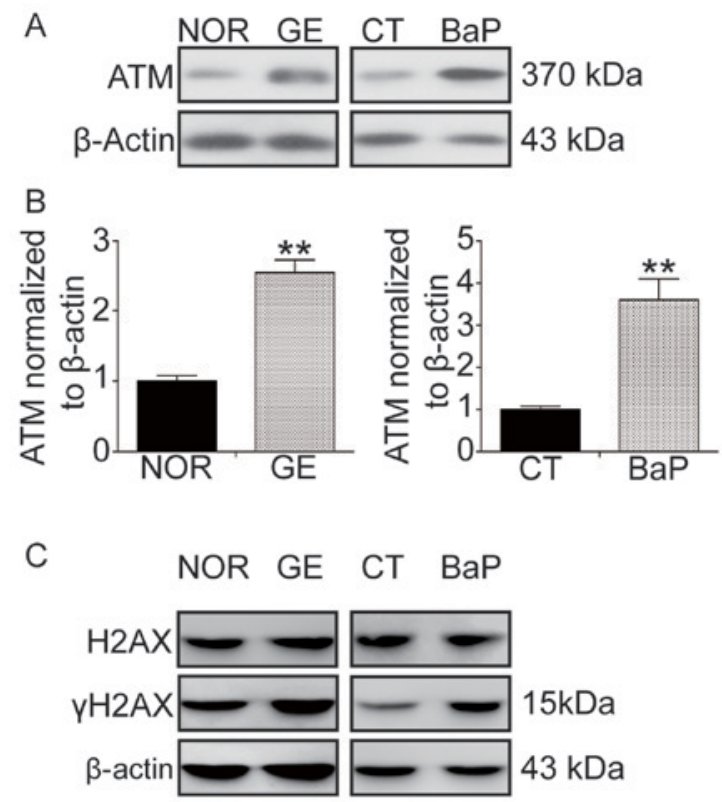

D
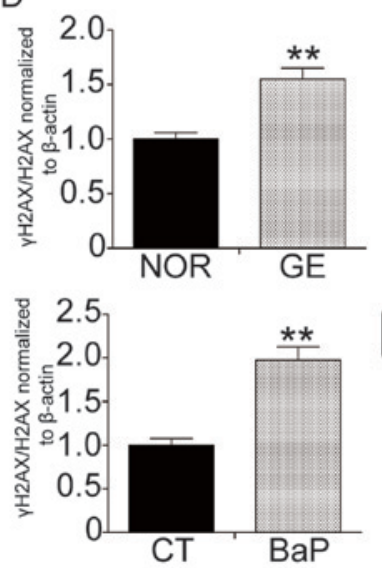

$E$

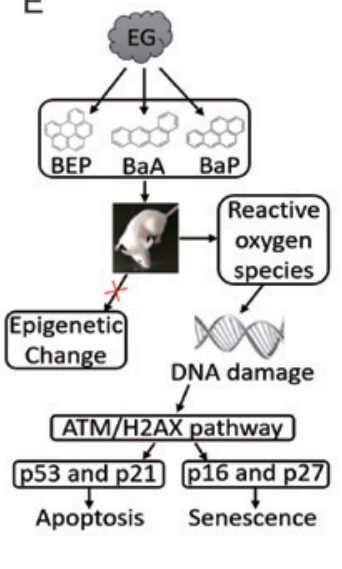

Figure 6. GE and BaP exposure activates the ATM/H2AX pathway in mouse lung tissues and lung fibroblast cells. Mice were exposed to EG or clean air for 30 days and sacrificed, and the lung tissues were collected and protein was extracted. mLFCs were treated with $3 \mu \mathrm{M} \mathrm{BaP}$ for $72 \mathrm{~h}$ and the protein was also extracted. (A) Protein expression levels of ATM assessed by western blotting. (B) Densitometric analysis of the protein expression levels of ATM (C) Protein expression levels of $\mathrm{H} 2 \mathrm{AX}$ and $\gamma \mathrm{H} 2 \mathrm{AX}$ assessed by western blotting. (D) Densitometric analysis of the protein expression levels of $\gamma \mathrm{H} 2 \mathrm{AX}$. The ratio between $\mathrm{H} 2 \mathrm{AX}$ and $\gamma \mathrm{H} 2 \mathrm{AX}$ was determined, and expression levels were normalized to $\beta$-actin. (E) Diagram illustrating polycyclic aromatic hydrocarbons-promoted stress-induced premature senescence. ${ }^{* *} \mathrm{P}<0.01$ compared with the normal or control group. $\gamma \mathrm{H} 2 \mathrm{AX}$, phosphorylated-H2AX; ATM, ATM serine/threonine kinase; BaA, benzanthracene; BaP, benzopyrene; BEP, benzoperylene; CT, control mLFCs; EG, exhaust gas; GE, gas exposure; H2AX, H2A histone family member X; mLFC, mouse lung fibroblast cell; NOR, normal (clean air).

alterations, including cytosine methylation (35). Methylation of the p16 promoter is used as a marker of genomic hypermethylation (36). Furthermore, the hypermethylation of $\mathrm{CpG}$ islands in the p16 promoter has been identified to be an early event in lung cancer development; particularly in patients with a history of exposure to cigarette smoke (37). In the present study, using the bisulfite sequencing method, it was suggested that exposure to EG and PAH was not sufficient to affect the methylation status of the p16 promoter. Therefore, these present results, in combination with the results of the 
telomere length assay, suggested that PAH may induce SIPS and not RS.

Since DNA damage is a marker of SIPS, activation of the ATM/H2AX pathway was examined. The ATM/H2AX pathway is activated by DNA damage and regulates DNA repair (38). The present western blotting results suggested that exposure to EG and $\mathrm{PAH}$ upregulated the protein expression levels of ATM and $\gamma \mathrm{H} 2 \mathrm{AX}$ in mLFCs. A previous study demonstrated that the reactive oxygen species formed following exposure to $\mathrm{BaP}$ generate detrimental oxidative effects on cell proliferation and cell survival via an increase in membrane lipid peroxidation and oxidative DNA damage (16). Barascu et al (29) reported that oxidative stress may induce an ATM-independent senescence response via the p38 MAPK pathway. Therefore, SIPS induced by PAHs in vivo and in vitro may be associated with the oxidative stress-induced DNA damage response.

Collectively, the present study suggested that exposure to PAH may induce apoptosis of mLFCs and increase the protein expression levels of various apoptosis-associated factors, including p53, p21, caspase-3 and caspase-9. Additionally, exposure to PAH was revealed to generate a SIPS response in mLFCs, upregulating the expression levels of p16 and p27. Exposure to PAH did not influence the epigenetic status of the promoter of p16; however, PAH was identified to induce SIPS via activation of the ATM pathway, which may be initiated by reactive epoxides and oxidative effects of PAHs (Fig. 6E). The present study may provide novel insights into the underlying mechanism of vehicle EG and PAHs in promoting the development of age-associated diseases.

\section{Acknowledgements}

Not applicable.

\section{Funding}

The present study was supported financially by The National Natural Science Foundation of China (grant no. 51306070).

\section{Availability of data and materials}

The datasets used and/or analyzed during the current study are available from the corresponding author on reasonable request.

\section{Authors' contributions}

DQ contributed to the design of the study and wrote the manuscript. FY and KY performed the experiments and analyzed the data. YH contributed to the design of the study. JL was involved in conducting the experiments. YA analyzed data, providing constructive comments. All authors read and approved the final manuscript.

\section{Ethics approval and consent to participate}

All animal experiments were approved by The Animal Care and Use and Ethics Committee on The Use of Animals of Jilin University.

\section{Patient consent for publication}

Not applicable.

\section{Competing interests}

The authors declare that they have no competing interests.

\section{References}

1. Gatto NM, Henderson VW, Hodis HN, St John JA, Lurmann F, Chen JC and Mack WJ: Components of air pollution and cognitive function in middle-aged and older adults in Los Angeles. Neurotoxicology 40: 1-7, 2014.

2. Ailshire JA and Clarke P: Fine particulate matter air pollution and cognitive function among U.S. older adults. J Gerontol B Psychol Sci Soc Sci 70: 322-328, 2015.

3. Thiering E, Cyrys J, Kratzsch J, Meisinger C, Hoffmann B, Berdel D, von Berg A, Koletzko S, Bauer CP and Heinrich J: Long-term exposure to traffic-related air pollution and insulin resistance in children: Results from the GINIplus and LISAplus birth cohorts. Diabetologia 56: 1696-1704, 2013.

4. Park SK, Adar SD, O'Neill MS, Auchincloss AH, Szpiro A Bertoni AG, Navas-Acien A, Kaufman JD and Diez-Roux AV: Long-term exposure to air pollution and type 2 diabetes mellitus in a multiethnic cohort. Am J Epidemiol 181: 327-336, 2015.

5. Franklin BA, Brook R and Arden Pope C III: Air pollution and cardiovascular disease. Curr Probl Cardiol 40: 207-238, 2015.

6. Meo SA and Suraya F: Effect of environmental air pollution on cardiovascular diseases. Eur Rev Med Pharmacol Sci 19: 4890-4897, 2015

7. Sax SN, Zu K and Goodman JE: Air pollution and lung cancer in Europe. Lancet Oncol 14: e439-e440, 2013.

8. Ding N, Zhou N, Zhou M and Ren GM: Respiratory cancers and pollution. Eur Rev Med Pharmacol Sci 19: 31-37, 2015.

9. Ward-Caviness CK, Nwanaji-Enwerem JC, Wolf K, Wahl S, Colicino E, Trevisi L, Kloog I, Just AC, Vokonas P, Cyrys J, et al: Long-term exposure to air pollution is associated with biological aging. Oncotarget 7: 74510-74525, 2016.

10. Mumaw CL, Surace M, Levesque S, Kodavanti UP, Kodavanti PRS, Royland JE and Block ML: Atypical microglial response to biodiesel exhaust in healthy and hypertensive rats. Neurotoxicology 59: 155-163, 2017.

11. Serra DS, Evangelista JSAM, Zin WA, Leal-Cardoso JH and Cavalcante FSA: Changes in rat respiratory system produced by exposure to exhaust gases of combustion of glycerol. Respir Physiol Neurobiol 242: 80-85, 2017.

12. Moorthy B, Chu C and Carlin DJ: Polycyclic aromatic hydrocarbons: from metabolism to lung cancer. Toxicol Sci 145: 5-15, 2015.

13. Bostrom CE, Gerde P, Hanberg A, Jernström B, Johansson C, Kyrklund T, Rannug A, Törnqvist $\mathrm{M}$, Victorin $\mathrm{K}$ and Westerholm R: Cancer risk assessment, indicators, and guidelines for polycyclic aromatic hydrocarbons in the ambient air. Environ Health Perspect 110 (Suppl 3): S451-S488, 2002.

14. Osgood RS, Upham BL, Hill T III, Helms KL, Velmurugan K, Babica P and Bauer AK: Polycyclic aromatic hydrocarbon-induced signaling events relevant to inflammation and tumorigenesis in lung cells are dependent on molecular structure. PLoS One 8: e65150, 2013.

15. Eom SY, Yim DH, Moon SI, Youn JW, Kwon HJ, Oh HC, Yang JJ, Park SK, Yoo KY, Kim HS, et al: Polycyclic aromatic hydrocarbon-induced oxidative stress, antioxidant capacity, and the risk of lung cancer: A pilot nested case-control study. Anticancer Res 33: 3089-3097, 2013.

16. Zhao G, Wang Z, Huang Y, Ye L, Yang K, Huang Q, Chen X, Li G, Chen Y, Wang J and Zhou Y: Effects of Benzoapyrene on migration and invasion of lung cancer cells functioning by TNF- $\alpha$. J Cell Biochem 119: 6492-6500, 2018.

17. White AJ, Chen J, Teitelbaum SL, McCullough LE, Xu X, Hee Cho Y, Conway K, Beyea J, Stellman SD, Steck SE, et al: Sources of polycyclic aromatic hydrocarbons are associated with gene-specific promoter methylation in women with breast cancer. Environ Res 145: 93-100, 2016.

18. Kim YH,Lee YS, Lee DH and Kim DS: Polycyclic aromatic hydrocarbons are associated with insulin receptor substrate 2 methylation in adipose tissues of Korean women. Environ Res 150: 47-51, 2016. 
19. Zhu L, Wang J, Du Y and Xu Q: Research on PAHs fingerprints of vehicle discharges. Huan Jing Ke Xue 24: 26-29, 2003 (In Chinese)

20. Gordon MW, Yan F, Zhong X, Mazumder PB, Xu-Monette ZY, Zou D, Young KH, Ramos KS and Li Y: Regulation of p53-targeting microRNAs by polycyclic aromatic hydrocarbons: Implications in the etiology of multiple myeloma. Mol Carcinog 54: 1060-1069, 2015.

21. Callicott RJ and Womack JE: Real-time PCR assay for measurement of mouse telomeres. Comp Med 56: 17-22, 2006.

22. Livak KJ and Schmittgen TD: Analysis of relative gene expression data using real-time quantitative PCR and the 2(-Delta Delta C(T)) method. Methods 25: 402-408, 2001.

23. Farhat N, Thorin-Trescases N, Voghel G, Villeneuve L, Mamarbachi M, Perrault LP, Carrier M and Thorin E: Stress-induced senescence predominates in endothelial cells isolated from atherosclerotic chronic smokers. Can J Physio Pharmacol 86: 761-769, 2008.

24. Kural KC, Tandon N, Skoblov M, Kel-Margoulis OV and Baranova AV: Pathways of aging: Comparative analysis of gene signatures in replicative senescence and stress induced premature senescence. Bmc Genomics 17: 213-224, 2016.

25. Drummond D, Baravalle-Einaudi M, Lezmi G, Vibhushan S, Franco-Montoya ML, Hadchouel A, Boczkowski J and Delacourt C: Combined effects of in utero and adolescent tobacco smoke exposure on lung function in $\mathrm{C} 57 \mathrm{Bl} / 6 \mathrm{~J}$ mice. Environ Health Perspect 125: 392-399, 2017.

26. Kim SY, Lee JH, Kim HJ, Park MK, Huh JW, Ro JY, Oh YM, Lee SD and Lee YS: Mesenchymal stem cell-conditioned media recovers lung fibroblasts from cigarette smoke-induced damage. Am J Physiol Lung Cell Mol Physiol 302: L891-L908, 2012.

27. Furlong HC, Stampfli MR, Gannon AM and Foster WG: Cigarette smoke exposure triggers the autophagic cascade via activation of the AMPK pathway in mice. Biol Reprod 93: 93, 2015.

28. Sasaki M, Kajiya H, Ozeki S, Okabe K and Ikebe T: Reactive oxygen species promotes cellular senescence in normal human epidermal keratinocytes through epigenetic regulation of p16(INK4a.). Biochem Biophys Res Commun 452: 622-628, 2014.
29. Barascu A, Le Chalony C,Pennarun G, Genet D, Imam N, Lopez B and Bertrand P: Oxidative stress induces an ATM-independent senescence pathway through p38 MAPK-mediated lamin B1 accumulation. EMBO J 31: 1080-1094, 2012.

30. Burma S, Chen BP, Murphy M, Kurimasa A and Chen DJ: ATM phosphorylates histone $\mathrm{H} 2 \mathrm{AX}$ in response to DNA double-strand breaks. J Biol Chem 276: 42462-42467, 2001.

31. McManus KJ and Hendzel MJ: ATM-dependent DNA damage-independent mitotic phosphorylation of $\mathrm{H} 2 \mathrm{AX}$ in normally growing mammalian cells. Mol Biol Cell 16: 5013-5025, 2005.

32. Silva GS, Fe LML, Silva MNP and Val V: Ras oncogene and Hypoxia-inducible factor-1 alpha (hif- $1 \alpha$ ) expression in the Amazon fish Colossoma macropomum (Cuvier, 1818) exposed to benzo[a]pyrene. Genet Mol Biol 40: 491-501, 2017.

33. Sun Y, Miller CA III, Wiese TE and Blake DA: Methylated phenanthrenes are more potent than phenanthrene in a bioassay of human aryl hydrocarbon receptor (AhR) signaling. Environ Toxicol Chem 33: 2363-2367, 2014

34. Aubert G: Telomere dynamics and aging. Prog Mol Biol Transl Sci 125: 89-111, 2014.

35. Herbstman JB, Tang D, Zhu D, Qu L, Sjödin A, Li Z, Camann D and Perera FP: Prenatal exposure to polycyclic aromatic hydrocarbons, benzo[a]pyrene-DNA adducts, and genomic DNA methylation in cord blood. Environ Health Perspect 120: 733-738, 2012.

36. Tessema M, Yu YY, Stidley CA, Machida EO, Schuebel KE, Baylin SB and Belinsky SA: Concomitant promoter methylation of multiple genes in lung adenocarcinomas from current, former and never smokers. Carcinogenesis 30: 1132-1138, 2009.

37. Belinsky SA, Nikula KJ, Palmisano WA, Michels R, Saccomanno G, Gabrielson E, Baylin SB and Herman JG: Aberrant methylation of p16(INK4a) is an early event in lung cancer and a potential biomarker for early diagnosis. Proc Natl Acad Sci USA 95: 11891-11896, 1998

38. Shiloh Y: The ATM-mediated DNA-damage response: Taking shape. Trends Biochem Sci 31: 402-410, 2006. International (CC BY-NC-ND 4.0) License. 